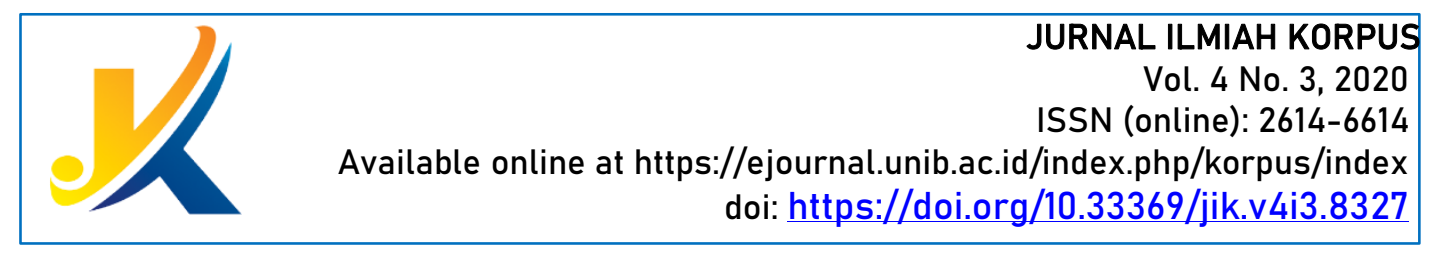

\title{
ANALISIS KESALAHAN PENGGUNAAN EJAAN DALAM TEKS HASIL OBSERVASI SISWA KELAS X SMAN 01 BENGKULU TENGAH
}

\author{
Yogi Prambana ${ }^{1}$, Rokhmat Basuki ${ }^{2}$, dan Supadi ${ }^{3}$ \\ Universitas Bengkulu
}

Korespondensi: yogiprambana15@gmail.com

\begin{abstract}
Abstrak
Tujuan penelitian ini adalah untuk mendeskripsikan Kesalahan Penggunaan Ejaan dalam Teks Hasil Observasi Siswa Kelas X SMAN 01 Bengkulu Tengah. Metode yang digunakan dalam penelitian ini adalah metode deskriptif. Teknik pengumpulan data dengan cara teknik catat. Data dalam penelitian ini berupa kata dan kalimat pada teks laporan hasil observasi karangan siswa pada kelas X IPA 3 SMAN 01 Bengkulu Tengah.Teknik pengumpulan data menggunakan teknik catat. Langkah-langkah yang dilakukan dengan mengumpulkan data, di beri kode di setiap kesalahan, mengidentifikasi data, mengklasifikasi data sesuai karakteristik atau ciri-ciri setiap unit data, data dianalisis sesuai dengan tujuan penelitian, dan menyimpulkan hasil penelitian. Berdasarkan hasil penelitian, kesalahan penggunaan ejaan sebagai berikut. 1) Kesalahan pemakaian huruf sebanyak $63,22 \%$ terdapat pada kesalahan penggunaan huruf kapital dan huruf miring, 2) Kesalahan penulisan kata sebanyak $16,71 \%$ terdiri dari kesalahan penulisan kata dasar, kata berimbuhan, kata ulang, gabungan kata, kata depan, ata partikel, singkatan dan akronim serta pada penulisan angka dan bilangan. 3) Kesalahan pemakaian tanda baca sebanyak 20,06\% terdiri dari kesalahan penggunaan tanda titik, tanda koma, tanda titik dua, tanda hubung, tanda tanya, tanda seru, dan tanda kurung.
\end{abstract}

Kata Kunci: Analisis, Ejaan, Laporan Hasil Observasi.

\section{Abstract}

The purpose of this study was to describe Spelling Usage Errors in the Texts of Observation Results of Class X SMAN 01 Bengkulu Tengah. The method used in this research is descriptive method. The technique of collecting data is by recording techniques. The data in this study are in the form of words and sentences in the text of the observation report written by students in class X IPA 3 of SMAN 01 Bengkulu Tengah. Techniques for collecting data using note-taking techniques. The steps taken by collecting data, given a code in each error, identifying data, classifying data according to the characteristics or characteristics of each unit of data, data analyzed according to the purpose of the study, and concluding the results of the study. Based on the results of the study, the misuse of spelling is as follows. 1) Letter usage error of $63.22 \%$ is found in the use of capital letters and italics, 2) Word writing errors of $16.71 \%$ consist of writing mistakes in basic words, affixed words, repeated words, combined words, prepositions, or particles, abbreviations and acronyms as well as numbers and numbers. 3) The use of punctuation errors of $20.06 \%$ consists of errors in the use of dots, commas, colons, hyphens, question marks, exclamation marks, and parentheses.

Keywords: Analysis, Spelling, Report on Observation Results. 


\section{PENDAHULUAN}

Bahasa adalah alat komunikasi yang tidak bisa dipisahkan dalam kehidupan manusia. Tanpa adanya bahasa manusia tidak bisa saling berinteraksi dan berkomunikasi satu sama lain. Dalam kehidupan manusia bahasa digunakan baik secara lisan maupun tulisan. Apabila situasi berkomunikasi itu tidak memungkinkan dipakai secara lisan, maka dipakailah dalam bentuk tulisan.

Banyak aspek yang harus dipelajari dalam proses menulis agar tulisan tersebut dapat dimengerti oleh pembacanya. Tulisan harus didasari dengan pedoman/kaidah yang merupakan aturan yang telah ditetapkan pemerintah melalui Menteri Pendidikan dan Kebudayaan Republik Indonesia Nomor 50 Tahun 2015 tentang Pedoman Umum Ejaan Bahasa Indonesia (PUEBI) (Kemendikbud, 2016:iv). Hal ini agar tulisan tidak mengalami kesalahan penulisan.

Kesalahan dalam penulisan sering terjadi. Kesalahan itu bisa berupa penggunaan huruf, kata atau tanda baca. Penulis hendaknya menguasai aturan ejaan yang merupakan aturan dalam tulisan agar tulisannya benar dan mudah untuk dipahami. Hal ini sudah diajarkan dalam pembelajaran bahasa Indonesia di sekolah untuk para siswa mengenai Ejaan Bahasa Indonesia (EBI).

Ejaan adalah sebuah aturan yang sudah ditetapkan dalam pemakaian huruf, penulisan kata, dan tanda baca. Menurut Sarwoko (2007:13) ejaan adalah sebuah kesepakatan untuk menggunakan lambang bunyi tertentu dan tanda-tanda tertentu agar dapat saling memahami. Ejaan mengupayakan agar komunikasi tertulis sama baiknya dengan komunikasi lisan melalui tanda-tanda dan simbol-simbol yang sudah disepakati. Sedangkan menurut Pujiono (2013:99) ejaan merupakan kaidah-kaidah penulisan tanda baca, kata, dan huruf yang harus ditaati oleh para pemakai bahasa. Kaidah-kaidah penulisan diberikan dalam pembelajaran bahasa Indonesia.

Pada Kurikulum 2013, materi pembelajaran bahasa Indonesia di kelas X mencakup 5 teks, yaitu teks prosedur kompleks, teks eksposisi, teks anekdot, teks negosiasi, dan teks laporan hasil observasi. Ini dipelajari siswa menjadi dua semester. Semester pertama yang dipelajari adalah teks laporan hasil observasi, teks prosedur, dan teks eksposisi, sedangkan pada semester kedua yang dipelajari adalah teks anekdot dan teks negosiasi.

Menurut Priyatni (2014: 76) teks laporan hasil observasi adalah teks yang menyampaikan informasi tentang sesuatu apa adanya sebagai hasil pengamatan dan analisis sistematis. Teks laporan hasil observasi bertujuan untuk menginformasikan kondisi objektif sesuatu yang diamati dan dianalisis secara sistematis, tidak dibumbui dengan respons pribadi tentang objek yang dilaporkan tersebut.

Penulis mengambil objek di SMAN 01 Bengkulu Tengah karena sekolah tersebut merupakan sekolah yang menjadi sekolah favorit di Kabupaten Bengkulu Tengah. Siswa yang masuk di sekolah ini diseleksi melalui tes tertulis. Siswa yang masuk sekolah ini merupakan siswa yang memiliki pengetahuan yang baik dan pintar sesuai dengan hasil tes tertulis yang sekolah berikan sesuai dengan kritria penilaian di atas 60 dari 100 soal yang harus dijawab. Siswa di sekolah tersebut juga memiliki latar belakang bahasa yang berbeda-beda dan hal ini mempengaruhi karangan yang dibuat siswa. Data observasi ketika membuat sebuah karangan siswa tersebut masih banyak penggunaan ejaan yang salah. 
Beberapa penelitian yang relevan dengan penelitian ini yang pertama adalah penelitian Isma Rusan Farhani (2015) “Analisis Kesalahan EYD (Ejaan yang Disempurnakan) Pada Buku Teks Bahasa Indonesia Ekspresi Diri Dan Akademik Kelas X Kurikulum 2013”. Penelitian yang kedua oleh Guntari Rahma Wanti (2016) "Analisis Kesalahan Ejaan Pada Kolom "Borgol" Surat Kabar Harian Rakyat Bengkulu”.

Persamaan penelitian ini dengan kedua penelitian di atas yaitu sama-sama menganalisis kesalahan penggunaan Ejaan Bahasa Indonesia (EBI). Perbedaan penelitian yang sudah dilakukan oleh Isma Rusan Farhani (2015) yang dianalisis adalah buku teks yang dibuat oleh para ahli, penelitian Guntari Rahma Wanti (2016) yang di analisis adalah tulisan seorang wartawan di surat kabar, sedangkan penelitian ini yang dianalisis adalah tulisan siswa kelas X SMAN 01 Bengkulu Tengah. Jadi dapat disimpulkan dari kedua penelitian di atas dengan penelitian ini terdapat persamaan dalam menganalisis kesalahan Ejaan, sedangkan yang menjadi pembeda, yaitu penelitian ini menganalisis tulisan yang dibuat oleh siswa.

Berdasarkan latar belakang di atas, maka rumusan masalah yang dikaji dalam penelitian ini adalah (1) Bagaimana kesalahan pemakaian huruf dalam teks laporan hasil observasi siswa kelas X SMAN 01 Bengkulu Tengah? (2) Bagaimana kesalahan penulisan kata dalam teks laporan hasil observasi siswa kelas X SMAN 01 Bengkulu Tengah? (3) Bagaimana kesalahan pemakaian tanda baca dalam teks laporan hasil observasi siswa kelas X SMAN 01 Bengkulu Tengah?

Definisi istilah (1) Analisis kesalahan adalah sebuah proses mengkaji dengan menemukan kesalahan yang menyimpang kaidahnya. (2) Ejaan adalah sebuah kesepakatan untuk menggunakan lambang bunyi tertentu dan tanda-tanda tertentu agar dapat saling memahami (Sarwoko, 2007:13). (3) Teks adalah satuan lingual yang dimediakan secara tulis dengan tata organisasi tertentu untuk mengungkapkan makna secara kontekstual (Priyatni, 2014:65). (4) Teks laporan hasil observasi adalah teks yang menyampaikan informasi tentang sesuatu apa adanya sebagai hasil pengamatan dan analisis secara sistematis (Priyatni, 2014:76). (5) Siswa adalah orang yang sedang melakukan kegiatan belajar mengajar.

Landasan teori dalam penelitian ini adalah Peraturan Menteri Pendidikan Dan Kebudayaan Republik Indonesia Nomor 50 Tahun 2015 memberlakukan tentang Pedoman Umum Ejaan Bahasa Indonesia (PUEBI). Menurut Kamus Besar Bahasa Indonesia (2005:250) ejaan adalah kaidah-kaidah cara bunyi-bunyi (kata, kalimat, dan sebagainya) dalam bentuk tulisan (huruf-huruf) serta penggunaan tanda baca. Atau, Menurut Sarwoko (2007:13), ejaan adalah sebuah kesepakatan untuk menggunakan lambang bunyi tertentu dan tanda-tanda tertentu agar dapat saling memahami. Sedangkan menurut Pujiono (2013:99) Ejaan yang Disempurnakan merupakan kaidah-kaidah penulisan tanda baca dan huruf yang harus ditaati oleh para pemakai bahasa.

Jadi, ejaan adalah keseluruhan peraturan bagaimana melambangkan bunyi ujaran dan bagaimana antar hubungan antara lambang-lambang itu (pemisahan dan penggabungannya dalam suatu bahasa). Secara teknis, yang dimaksud dengan ejaan adalah penulisan huruf, penulisan kata, dan pemakaian tanda baca.

Secara garis besarnya, ruang lingkup ejaan dalam PUEBI terdiri dari hal-hal sebagai berikut:

a) Pemakaian huruf terdiri dari: 1) Huruf kapital, huruf-huruf kapital atau huruf besar dalam sebuah kamus bukan saja dipergunakan untuk kata-kata kepala yang perlu 
mendapat huruf kapital, tetapi juga huruf awal baik dari kata dasarnya maupun unsur tambahan yang ditempatkan pada awal kata itu (Keraf, 1994:53). 2) Huruf miring, pada penggunaan huruf miring digunakan dalam cetakan. Dalam tulisan yang akan dicetak miring, diberi garis bawah tunggal (Suparlan, 2014).

b) Penulisan Kata, Kata ialah satuan bebas yang paling kecil, atau dengan kata lain, setiap satu kesatuan bebas merupakan kata (Ramlan, 2001:33). Penulisan kata terdiri dari: 1) Kata dasar, kata yang berupa kata dasar ditulis sebagai satu kesatuan. 2) Kata berimbuhan, awalan, sisipan, akhiran, serta gabungan awalan dan akhiran ditulis serangkai. 3) Bentuk ulang ditulis dengan menggunakan tanda hubung (-) di antara unsur-unsurnya.4) Gabungan Kata. 5) Kata depan, menurut Matanggui dan Zaenal Arifin (2014:26) Kata depan, seperti di, ke, dan dari, ditulis terpisah dari kata benda dan kata benda lokatif yang mengikutinya. 6) Partikel, menurut Murtiani, dkk (2016:37) partikel adalah kata yang biasanya tidak dapat diderivasikan atau diinfleksikan, termasuk di dalamnya artikel, preposisi, konjungsi, dan interjeksi. Partikel adalah kata yang tidak tertakluk pada perubahan bentuk dan hanya berfungsi menampilkan unsur yang diiringinya. 7) Singkatan dan akronim, singkatan adalah bentuk yang lebih ringkas dari istilah atau kelompok kata dengan mengambil huruf awalnya (Sarwoko, 2007:94) dan akronim adalah singkatan yang berupa gabungan huruf awal, gabungan suku kata, atau gabungan huruf dan suku kata dari deret kata yang diperlukan sebagai kata.

c) Pemakaian tanda baca, pada penggunaan huruf miring sumber yang dipakai dari selain buku dari (kemendikbud, 2016). Pemakaian tanda baca terdiri dari: 1) Tanda titik adalah tanda baca yang digunakan untuk menandai akhir dari sebuah kallimat dalam berbagai bahasa. Tanda ini terdiri atas titik kecil yang ditempatkan di akhir suatu baris dari sebuah kalimat, seperti di akhir kalimat (Suparlan, 2014:47). 2) Tanda koma adalah tanda baca yang memiliki bentuk mirip apostrof atau tanda petik tunggal tapi diletakkan di garis dasar teks. Beberapa jenis huruf menggambarkannya sebagai suatu garis kecil yang agak melengkung atau kadang lurus, atau seperti angka sembilan yang diisi bagian lubangnya (Waridah,2014:190). 3) Tanda titik dua adalah tanda baca yang dilambangkan dengan dua titik berukuran sama yang diletakkan di tengah garis vertikal yang sama. Seperti halnya tanda baca lain, penggunaan tanda titik dua bervariasi antara sebagai bahasa dan bahkan pada bahasa yang sama pada periode yang berbeda. Secara aturan umum, tanda titik dua memberitahukan pembaca bahwa uraian setelah tanda ini memberi bukti dan menjelaskan, atau merupakan unsur dari apa yang sudah dijelaskan sebelum tanda tersebut (Suparlan 2014:56). 4) Tanda hubung adalah tanda baca yang digunakan untuk menghubungkan dua kata atau memisahkan dua suku kata (Waridah, 2014:197). 5) Tanda hubung adalah tanda baca yang digunakan untuk menghubungkan dua kata atau memisahkan dua suku kata (Waridah, 2014:197). 6) Tanda seru dipakai untuk mengakhiri ungkapan atau pernyataan yang berupa seruan atau perintah yang menggambarkan kesungguhan, ketidakpercayaan, atau emosi yang kuat (Permendiknas RI No. 46 Th. 2009, 2012:55). 7) Tanda kurung adalah tanda baca yang digunakan secara berpasangan untuk memisahkan atau menyisipkan teks kedalam teks lain (Sarwoko, 2007:34).

Teks laporan hasil observasi adalah teks yang menyampaikan informasi tentang sesuatu apa adanya sebagai hasil pengamatan dan analisis sistematis (Priyatni, 2014:76). 


\section{Analisis Kesalahan Penggunaan Ejaan Dalam Teks Hasil...}

Teks laporan juga disebut teks klasifikasi karena teks tersebut memuat klasifikasi mengenai jenis-jenis sesuatu berdasarkan kriteria tertentu (Kemendikbud, 2013:3).

Menurut Priyatni (2014:77) teks laporan hasil observasi memiliki struktur isi sebagai berikut, 1) Judul, Judul teks laporan hasil observasi sudah memunculkan ciri khas dari sesuatu yang hendak diinformasikan, 2) Klasifikasi umum, berisi pengenalan fenomena benda yang akan dibicarakan dengan menyertakan pernyataan umum yang menerangkan subjek laporan, keterangan, dan klasifikasinya, dan 3) deskripsi, Berisi gambaran dari fenomena/benda yang diamati dari bagian ke bagiannya, kebiasaan atau tingkah laku untuk makhluk hidup, atau kegunaannya untuk benda.

\section{METODE}

Metode yang digunakan dalam penelitian ini adalah metode deskriptif. Metode deskriptif dalam penelitian ini dimaksudkan untuk mendeskripsikan atau menggambarkan kesalahan ejaan dalam teks laporan hasil observasi siswa kelas X SMAN 01 Bengkulu Tengah.

Sumber data dalam penelitian ini adalah karangan siswa kelas X IPA 3 SMAN 01 Bengkulu Tengah di Kabupaten Bengkulu Tengah yang beralamat di jalan lintas Bengkulu - Curup KM. 12, Desa Kembang Seri, Kecamatan Talang Empat, Kabupaten Bengkulu Tengah.

Data dalam penelitian ini adalah kalimat-kalimat pada karangan yang ada hubungannya dengan rincian masalah berupa kesalahan penggunaan ejaan siswa kelas $\mathrm{X}$ SMAN 01 Bengkulu Tengah. Data terdiri dari 30 teks laporan hasil observasi karangan siswa pada kelas X IPA 3 SMAN 01 Bengkulu Tengah.

Penelitian ini dilaksanakan di SMAN 01 Bengkulu Tengah. Pelaksanaan penelitian ini dilakukan pada tanggal 02 Mei 2018 sampai dengan 02 Juni 2018.

Teknik pengumpulan data yang dilakukan dalam penelitian ini yang pertama mengumpulkan data yaitu mengumpulkan karangan teks laporan hasil observasi siswa kelas X IPA. Tahap kedua penulis membaca karangan yang telah terkumpul untuk menemukan kesalahan ejaan dalam teks laporan hasil observasi tersebut. Teknik selanjutnya yang digunakan adalah teknik catat.

Menurut Sudaryanto (1998:5), teknik catat dilakukan dengan cara mencatat data yang segera dilanjutkan dengan klasifikasi. Dalam hal ini penulis mencatat data yang berupa kalimat-kalimat yang terdapat kesalahan ejaan bahasa Indonesia dalam teks laporan hasil observasi siswa kelas X SMAN 01 Bengkulu Tengah di tabel klasifikasi.

Langkah-langkah yang dilakukan untuk menganalisis data dalam penelitian ini sebagai berikut: 1) Mengumpulkan data berupa karangan teks laporan hasil observasi siswa kelas X SMAN 01 Bengkulu Tengah, 2) Data yang dikumpulkan selanjutnya di beri kode di setiap kesalahan ejaan yang terdapat di teks laporan hasil observasi siswa kelas X SMAN 01 Bengkulu Tengah. Pemberian kode berupa nomor dan huruf untuk memudahkan peneliti dalam menganalisis data, 3) Mengidentifikasi data yang terdapat kesalahan ejaan pada teks laporan hasil observasi siswa kelas X SMAN 01 Bengkulu Tengah, 4) Mengklasifikasi data dengan memperhatikan karakteristik atau ciri-ciri setiap unit data berdasarkan kesalahan yang sama, 5) Data yang dikelompokkan selanjutnya dianalisis sesuai dengan tujuan penelitian, yaitu untuk memperoleh gambaran bagaimana kesalahan penulisan ejaan bahasa Indonesia dalam teks laporan hasil observasi siswa kelas X SMAN 01 Bengkulu Tengah, dan 6) Menyimpulkan hasil analisis yang terdapat 
kesalahan ejaan dalam teks laporan hasil observasi siswa kelas X SMAN 01 Bengkulu Tengah.

\section{HASIL PENELITIAN DAN PEMBAHASAN}

Pada bab ini akan diuraikan data hasil penelitian dan pembahasan. Hasil penelitian ini diperoleh pada naskah teks laporan hasil observasi siswa kelas X SMAN 01 Bengkulu Tengah yang masih terdapat kesalahan ejaan bahasa Indonesia pada penulisan teks. Penulis menganalisis kesalahan ejaan bahasa berdasarkan Pedoman Umum Ejaan Bahasa Indonesia, yaitu (1) pemakaian huruf, (2) penulisan kata, dan (3) tanda baca. Untuk itu, bagian bab ini yang terdiri dari hasil penelitian, dan pembahasan satu persatu secara berturut-turut seperti berikut.

A. Hasil Penelitian

Hal yang dibahas yaitu ada tiga, yakni kesalahan pemakaian huruf, kesalahan penulisan kata, dan kesalahan penggunaan tanda baca. Data dan ananlisis setiap aspek akan diuraikan sebagai berikut.

1) Kesalahan pemakaian Huruf

Analisis kesalahan pemakaian huruf terdiri atas (1) kesalahan penggunaan huruf kapital dan (2) kesalahan penggunaan huruf miring.

a) Kesalahan Penggunaan Huruf Kapital

Kesalahan pemakaian huruf kapital pada teks laporan hasil observasi siswa kelas X SMAN 01 Bengkulu Tengah ditemukan sebanyak 161 kesalahan. Berikut ini data kesalahan serta perbaikannya.

sampah merupakan material sisa yang tidak diinginkan setelah berakhirnya suatu proses. (I/1/R19/1/1/82)

pohon kelapa (cocos nucifera) atau disebut juga pohon nyiur. (I/1/R26/1/1/83)

Pada huruf yang dicetak tebal pada data terdapat kesalahan penggunaan huruf kapital, yaitu pada kata sampah dan pohon. Pada penulisan penggunaan huruf kapital pada kata sampah dan pohon itu tidak tepat. Kaidah yang benar penggunaan huruf kapital pada setiap awal kalimat. Sehingga penulisan yang benar sebagai berikut:

Sampah merupakan material sisa yang tidak diinnginkan setelah berakhirnya suatu proses. (I/1/R19/1/1/82)

Pohon kelapa (cocos nucifera) atau disebut juga pohon nyiur. (I/1/R26/1/1/83)

b) Kesalahan Penggunaan Huruf Miring

Kesalahan penggunaan huruf miring dalam teks laporan hasil observasi siswa kelas X SMAN 01 Bengkulu Tengah ditemukan sebanyak 47 kesalahan. Berikut ini data kesalahan serta perbaikannya.

Tumbuhan lain seperti asam (tamarindus indica), gadang (dioscorea hispida), kemiri (aleuretis moleccana), gebang (cirypha utan), api-api (aricennea sp), kendal (cordia op liqua), manting (syzygium polyanthum), dan kepuh

Penulisan huruf yang di cetak tebal pada data tidak sesuai dengan kaidah bahasa Indonesia, karena pada kata Tumbuhan lain seperti asam (tamarindus indica), (dioscorea hispida),(aleuretis moleccana), (cirypha utan), (aricennea sp), (cordia op liqua), (syzygium polyanthum), (sterculia foelida), kata-kata tersebut tidak dimiringkan. Kaidah yang benar pemakaian huruf miring untuk menuliskan kata nama ilmiah, ungkapan asing, dan daerah kecuali yang telah disesuaikan ejaannya. Berikut perbaikan yang benar: 
Tumbuhan lain seperti asam (tamarindus indica), gadang (dioscorea hispida), kemiri (aleuretis moleccana), gebang (cirypha utan), api-api (aricennea sp), kendal (cordia op liqua), manting (syzygium polyanthum), dan kepuh (sterculia foelida). $(\mathrm{I} / 2 / \mathrm{R} 3 / 3 / 1 / 85)$

2) Penulisan Kata

Kesalahan penulisan kata dalam teks laporan hasil observasi siswa kelas X SMAN 01 Bengkulu Tengah ditemukan sebanyak 55 kesalahan. Berdasarkan hasil analisis data, kesalahan penulisan kata yang penulis temukan dalam data terdapat pada delapan aspek kesalahan. Berikut kesalahan yang dilakukan oleh siswa.

a) Kata Dasar

Orang utan umumnya banyak di jumpai, disekitar pulau sumatrah dan kalimantan. (I/3/R13/ 1/4/89)

Penulisan kata dasar pada tidak sesuai dengan kaidah bahasa Indonesia, yaitu kata sumatrah seharusnya yang benar adalah Sumatera. Kaidah yang benar penulisan kata dasar sebagai satu kesatuan yang sudah di tentukan sesuai aturan ejaan. Berikut perbaikan yang benar:

Orang utan umumnya banyak di jumpai, disekitar pulau sumatera dan Kalimantan. (I/3/R13/ 1/4/89)

b) Kata Berimbuhan

Beberapa Orang utan umumnya banyak di Jumpai, disekitar pulau sumatrah dan Kalimantan. (I/4/R13/ 1/4/90)

Penulisan kata berimbuhan pada data tidak sesuai dengan kaidah bahasa Indonesia, yaitu kata di Jumpai seharusnya tidak dipisah. Kaidah yang benar imbuhan (awalan, sisipan, akhiran) ditulis serangkai dengan bentuk dasarnya. Berikut perbaikan yang benar:

Orang utan umumnya banyak dijumpai, disekitar pulau sumatera dan Kalimantan. (I/4/R13/ 1/4/90)

Secara lengkap data kesalahan pemakaian huruf kapital dapat dilihat pada tabel lampiran I.

c) Bentuk Ulang

Ana anak suku badui dalam Pun tidak bersekolah, kegiatan hanya sekitar sawah dan kebun. (I/5/R18/4/3/90)

Penulisan bentuk ulang pada data tidak sesuai dengan kaidah bahasa Indonesia, yaitu kata ana anak. Kaidah yang benar penulisan bentuk ulang seharusnya diberi tanda hubung (-). Berikut perbaikan yang benar:

Anak-anak suku Badui dalam pun tidak bersekolah, kegiatan hanya sekitar sawah dan kebun. (I/5/R18/4/3/90)

Secara lengkap data kesalahan penulisan singkatan dan akronim dapat dilihat pada tabel lampiran I.

d) Gabungan Kata

Beberapa data yang menunjukan keane karagaman komposisi tumbuhan ekosistem mangrove di Pulau Enggano. (I/6/R10/6/1/90)

Penulisan gabungan kata pada data tidak sesuai dengan kaidah bahasa Indonesia, yaitu kata keane karagaman seharusnya tidak dipisah. Kaidah yang benar gabungan kata yang mendapat awalan dan akhiran sekaligus ditulis serangkai. Berikut perbaikan yang benar: 
Beberapa data yang menunjukan keanekaragaman komposisi tumbuhan ekosistem mangrove di pulau Enggano. (I/6/R10/6/1/90)

e) Kata Depan

Terdapat banyak hewan disetiap daerah, muai dari hewan yang hidup didarat, diair dan diudara. $(\mathrm{I} / 7 / \mathrm{R} 1 / 1 / 2 / 91)$

Penulisan kata depan pada data tidak sesuai dengan kaidah bahasa Indonesia, yaitu kata didarat, diair dan diudara. Kaidah yang benar kata di- sebagai kata depan menyatakan arah atau tempat dan merupakan jawaban dari pertanyaan di mana harus dituliskan terpisah dengan kata yang mengikutinya. Berikut perbaikan yang benar:

Terdapat banyak hewan disetiap daerah, muai dari hewan yang hidup di darat, di air dan di udara. (I/7/R1/ 1/2/91)

f) Partikel

Itu lah salah satu keunikan suku Badui sehingga wajar mereka sangat menjaga betul "pikukuh" atau ajaran mereka, entah berupa kepercayaan dan kebudayaan. (I/8/R18/1/4/96)

Penulisan partikel pada data tidak sesuai dengan kaidah bahasa Indonesia, yaitu kata Itu lah. Kaidah yang benar penulisan partikel -lab ditulis serangkai dari kata yang mendahuluinya. Berikut perbaikan yang benar:

Itulah salah satu keunikan suku Badui sehingga wajar mereka sangat menjaga betul "pikukuh" atau ajaran mereka, entah berupa kepercayaan dan kebudayaan. (I/8/R18/1/4/96)

g) Singkatan dan Akronim

Dan Berdasarkan bentuk tubuhnya hewan memiliki perbedaan yg mencolok, mulai dari warna tubuhnya, ukuran tubuhnya, cara melindungi diri dan cara berkembang biak. (I/8/R18/4/3/96)

Penulisan singkatan pada data tidak sesuai dengan kaidah bahasa Indonesia, yaitu kata yg. Kaidah yang benar penulisan singkatan yang terdiri atas dua huruf yang lazim dipakai dalam surat-menyurat masing-masing diikuti oleh tanda titik. Berikut perbaikan yang benar:

Berdasarkan bentuk tubuhnya hewan memiliki perbedaan yang mencolok, mulai dari warna tubuhnya, ukuran tubuhnya, cara melindungi diri dan cara berkembang biak. (I/8/R18/4/3/96)

h) Angka dan Bilangan

Perbedaannya dengan manusia modern yaitu orang utan masih suka berpindah tempat ntuk mencari makan dan hanya menetap paling lama satu atau 2 kali disarang yang sama. (I/10/R13/3/5/98)

Penulisan angka pada data tidak sesuai dengan kaidah bahasa Indonesia, yaitu kata satu atau 2 kali. Kaidah yang benar penulisan angka dalam teks yang dapat dinyatakan dengan satu atau dua kata ditulis menggunakan huruf semua. Berikut perbaikan yang benar:

Perbedaannya dengan manusia modern yaitu orang utan masih suka berpindah tempat ntuk mencari makan dan hanya menetap paling lama satu atau dua kali disarang yang sama. (I/10/R13/3/5/98)

3) Penggunaan Tanda Baca

Pada pemakaian tanda baca terdapat 66 kesalahan dari tujuh aspek kesalahan. Kesalahan tersebut dapat terlihat seperti berikut: 
a) Tanda Titik (.)

Sekarang ada banyak hewan yang dilindungi oleh(.) Pemerintah karena banyak hewaan yang hampir punah akibat perburuan yang dilakukan oleh orang-orang yang tidak bertanggung jawab (I/11/R1/1/4/98)

Data tidak sesuai dengan kaidah bahasa Indonesia karena dalam Ejaan Bahasa Indonesia tanda titik dipakai pada akhir kalimat yang bukan pertanyaan atau pernyataan. Berikut perbaikan yang benar:

Sekarang ada banyak hewan yang dilindungi oleh pemerintah karena banyak hewaan yang hampir punah akibat perburuan yang dilakukan oleh orang-orang yang tidak bertanggung jawab. (I/11/R1/1/4/98)

b) Tanda Koma (,)

Hewan memiliki cara perkembangbiakan yang berbeda, yaitu hewan yang melahirkan, contohnya kambing kerbau harimau sapi panda gajah anjing kera beruang dan kelinci. (I/12/R1/2/3/100)

Data (tidak sesuai dengan kaidah bahasa Indonesia karena dalam Ejaan Bahasa Indonesia tanda koma dipakai di antara unsur-unsur dalam suatu pemerincian atau pembilangan. Data dapat diperbaiki sebagai berikut:

Hewan memiliki cara perkembangbiakan yang berbeda, yaitu hewan yang melahirkan, contohnya kambing, kerbau, harimau, sapi, panda, gajah, anjing, kera, beruang, dan kelinci. (I/12/R1/2/3/100)

c) Tanda Titik Dua (:)

Hewan memiliki cara perkembang biakan yang berbeda, yaitu hewan yang melahirkan, contohnya kambing, kerbau, harimau, sapi, panda, gajah, anjing, kera, beruang dan kelinci. (I/13/R1/2/2/104)

Data tidak sesuai dengan kaidah bahasa Indonesia karena dalam Ejaan Bahasa Indonesia tanda titik dua dipakai pada akhir suatu pernyataan lengkap yang diikuti pemerincian atau penjelasan. Data dapat diperbaiki sebagai berikut:

Hewan memiliki cara perkembang biakan yang berbeda, yaitu hewan yang melahirkan, contohnya: kambing, kerbau, harimau, sapi, panda, gajah, anjing, kera, beruang dan kelinci. (I/13/R1/2/2/104)

Secara lengkap data kesalahan penulisan singkatan dan akronim dapat dilihat pada tabel lampiran I.

d) Tanda Hubung (-)

Taman nasional Baluran memi

liki berbagai macam flora dan fauna serta ekosistem. (I/14/R3/1/5/106)

Data tidak sesuai dengan kaidah bahasa Indonesia karena dalam Ejaan Bahasa Indonesia tanda hubung dipakai untuk menandai bagian kata yang terpenggal oleh pergantian baris. Data dapat diperbaiki sebagai berikut:

Taman nasional Baluran memi-

liki berbagai macam flora dan fauna

serta ekosistem. (I/14/R3/1/5/106)

e) Tanda Seru (!)

Sekarang ada banyak hewanyang dilindungi oleh pemerintah karena banyak hewan yang hampir punah akibat perburuan yang dilakukan oleh orang-orang yang tidak bertanggung jawab! (I/15/R1/1/6/108) 
Data tidak sesuai dengan kaidah bahasa Indonesia karena tidak terdapat tanda seru. Dalam Ejaan Bahasa Indonesia tanda seru dapat dipakai untuk memperjelas hubungan bagian kata atau ungkapan. Perbaikan dan pemberian tanda hubung pada data sebagai berikut:

Sekarang ada banyak hewan yang dilindungi oleh pemerintah karena banyak hewan yang hampir punah akibat perburuan yang dilakukan oleh orang-orang yang tidak bertanggung jawab. (I/15/R1/1/6/108)

f) Tanda Kurung $((\ldots))$

Diantara jenis tumbuhan disini terdapat tumbuhan asli yang khas dan menarik yaitu widoro bakau, mimba, dan pilang merupakan tumbuhan yang mampu bradaptasi dalam kondisi yang sangat kering (masih kelihatan hijau), walaupun tumbuhan lainnya sudah layu dan mengering. (I/16/R3/2/5/109)

Data tidak sesuai dengan kaidah bahasa Indonesia karena dalam Ejaan Bahasa Indonesia tanda kurung dipakai untuk mengapit keterangan atau penjelasan yang bukan bagian utama kalimat. Perbaikan dan pemberian tanda hubung pada data sebagai berikut:

Di antara jenis tumbuhan disini terdapat tumbuhan asli yang khas dan menarik yaitu widoro bakau, mimba, dan pilang merupakan tumbuhan yang mampu bradaptasi dalam kondisi yang sangat kering masih kelihatan hijau, walaupun tumbuhan lainnya sudah layu dan mengering. (I/16/R3/2/5/109)

B. Pembahasan

Pada pembahasan berikut ini penulis akan membagi menjadi tiga bagian pembahasan yaitu: kesalahan pemakaian huruf, kesalahan penulisan kata dan kesalahan penggunaan tanda baca. Pada penelitian ini banyak kesalahan yang ada pada cara penulisan siswa tersebut, baik itu pemakaian huruf, kata, dan tanda baca.

Hal ini dikarenakan siswa masih cenderung menggunakan bahasa yang tidak baik dan tidak benar dalam penulisan karangan tersebut, sehingga dalam penulisan karangan yang mereka lakukan menjadi tidak sesuai dengan Ejaan Bahasa Indonesia (EBI) secara baik dan benar.

Pada dasarnya siswa masih terdapat kesalahan dalam penggunaan dan pemilihan kata, sehingga siswa cenderung salah dalam pembentukan kata. Hal ini dibuktikannya banyak kesalahan pada penulisan siswa tersebut, mulai dari kesalahan:

(1) Pemakaian huruf 208 kesalahan yaitu huruf kapital 161 kesalahan dan huruf miring 47 kesalahan. Dari keseluruhan kesalahan penulisan pemakaian huruf dapat dihitung dengan rumus:

Nilai Rata - rata $=\frac{208}{329} \times 100=63,22 \%$

(2) Penulisan kata 55 kesalahan yaitu 2 kata dasar, 1 kata berimbuhan, 3 bentuk ulang, 2 gabungan kata, 35 kata depan, 1 partikel, 9 singkatan dan ankronim, serta 2 angka dan bilangan.

Nilai Rata - rata $=\frac{55}{329} \times 100=16,71 \%$

(3) Penggunaan tanda baca 66 kesalahan yaitu 9 tanda titik, 23 tanda koma, 7 tanda titik dua, 12 tanda hubung, 7 tanda tanya, 4 tanda seru, dan 4 tanda kurung.

Nilai Rata - rata $=\frac{66}{329} \times 100=20,06 \%$ 
Dengan adanya kondisi seperti ini menjadi pekerjaan rumah bagi kita semua sebagai guru bahasa Indonesia agar memberikan ilmu dasar mengenai ejaan kepada murid kita sendiri. Menurut penulis sendiri seorang guru menemukan kesalahan penulisan dibidang ejaan pada tulisan siswa setidaknya guru tersebut memberitahukan contoh yang sesuai dengan aturan ejaan yang benar agar siswa tersebut dapat lebih memahami bagaimana kepenulisan yang baik dan benar sesuai dengan Ejaan Bahasa Indonesia (EBI). Jika hal ini dilakukan setiap guru bahasa Indonesia, mudah-mudahan generasi penerus bangsa selanjutnya mengerti bagaimana penulisan yang benar dan sesuai aturan yang berlaku.

\section{PENUTUP}

\section{Kesimpulan}

Berdasarkan hasil penelitian, diketahui bahwa kesalahan penggunaan ejaan pada teks laporan hasil observasi siswa kelas X SMAN 01 Bengkulu Tengah sebagai berikut: (1) Kesalahan pemakaian huruf sebanyak $63,22 \%$ yang terdiri dari penggunaan huruf kapital dan huruf miring meliputi: awal kalimat, nama agama, nama Tuhan, nama instansi, nama bangsa, bahasa, nama tempat, daerah, nama geografi, dan di tengah atau di akhir, sementara pada pemakaian huruf miring terdapat kesalahan menuliskan kata atau ungkapan dalam bahasa daerah atau bahasa asing. (2) Kesalahan penulisan kata sebanyak $16,71 \%$ yang terdapat pada kesalahan penulisan kata dasar, kata berimbuhan, kata ulang, gabungan kata, kata depan, ata partikel, singkatan dan akronim serta pada penulisan angka dan bilangan. (3) Kesalahan pemakaian tanda baca sebanyak 20,06\% yang terdapat pada kesalahan penggunaan tanda titik, kesalahan tanda koma, kesalahan tanda titik dua, kesalahan tanda hubung, kesalahan tanda tanya, kesalahan tanda seru, dan kesalahan tanda kurung.

\section{Saran}

Berdasarkan hasil dan pembahasan dari penelitian ini, dapat diberikan beberapa saran. Saran-saran tersebut adalah sebagai berikut: (1) Penulis mengharapkan terdapat penelitian selanjutnya mengenai analisis penggunaan ejaan lainnya sehingga dapat ditemukan kesalahaan lain dari teks laporan hasil observasi siswa kelas X SMAN 01 Bengkulu Tengah dan juga sebagai inspirasi untuk melakukan penelitian yang lebih mendalam, dan (2) Kepada guru, agar dapat menggunakan penelitian ini sebagai salah satu sumber referensi dalam pembelajaran terutama dengan adanya kondisi seperti ini menjadi pekerjaan rumah bagi kita semua sebagai guru bahasa Indonesia agar memberikan ilmu dasar mengenai ejaan kepada murid kita sendiri.

\section{DAFTAR PUSTAKA}

Djadjasudarma, T. Fatimah. 1993. Metode Linguistik Ancangan Metode Penelitian dan Kajian. Bandung: Eresco.

Farhani, Isma Rusan. 2015. Analisis Kesalaban Eyd (Ejaan Yang Disempurnakan) Pada Buku Teks Bahasa Indonesia Ekespresi Diri Dan Akademik Kelas X Kurikulum 2013. Skripsi: FITK UIN Syarrif Hidayatullah.

Kemendikbud. 2016. Pedoman Umum Ejaan Bahasa Indonesia. Jakarta: Badan Pengembangan dan Pembinaan Bahasa. 
Matanggui, Junaiyah H dan Zaenal Arifin. 2014. Analisis Kesalahan Berbahasa Indonesia. Tangerang: Pustaka Mandiri.

Murtiani, Anjar, Fita Nur Arifah dan Lia Noviastuti. 2016. Pedoman Umum EBI Ejaan Bahasa Indonesia. Yogyakarta: Araska.

Priyatni, Endah Tri. 2014. Desain Pembelajaran Bahasa Indonesia dalam Kurikulum 2013. Jakarta: Bumi Aksara.

Pujiono, Setyawan. 2013. Terampil Menulis: Cara Mudah dan Praktik dalam Menulis. Yogyakarta: Graha Ilmu.

Sarwoko, Tri Adi. 2007. Inilah Bahasa Indonesia Jurnalistik. Yogyakarta: ANDI.

Sudaryanto. (1988). Penelitian Kualitatif. Yogyakarta: Gadjah Mada University Press.

Suparlan. 2014. Panduan Lengkap Ejaan Yang Disempurnakan. Yogyakarta: Pustaka Baru.

Rahmawanti, Guntari. 2016. Analisis Kesalahan Ejaan Pada Kolom "Borgol" Surat Kabar Harian Rakyat Bengkulu. Skripsi: FKIP Universitas Bengkulu.

Waridah, Ernawati. 2014. Pedoman Kata Baku dan Tidak Baku. Bandung: Ruang Kata. 